\title{
Affect-based stock investment decision: The role of affective self-affinity
}

\author{
Naime Usul ${ }^{\mathrm{a}, *}$, Özlem Özdemir ${ }^{\mathrm{b}}$, Timothy Kiessling ${ }^{\mathrm{c}}$ \\ a Faculty of Business Administration, Bilkent University, Ankara, 06800, Turkey \\ ${ }^{\mathrm{b}}$ Faculty of Economics and Administrative Sciences, Department of Business Administration, Middle East Technical University, Ankara, 06800, Turkey

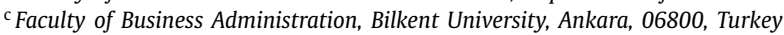

\section{A R T I C L E I N F O}

\section{Article history:}

Received 20 September 2016

Revised 12 April 2017

Accepted 13 April 2017

Available online 19 April 2017

\section{Keywords:}

Investor behavior

Investor psychology

Affect heuristic

Affective self-affinity

Social identity theory

Antecedents of affective self-affinity

\begin{abstract}
A B S T R A C T
This paper studies the role of affective self-affinity for a company in the stock investment decision by investigating the factors triggering it. Based on the social identity theory and the affect literature we hypothesize that three types of identifications, namely group related, company-people related and idea/ideal related, trigger affective self-affinity for a company which results in extra affect-based motivation to invest in the company's stock. The two ideas included in the idea/ideal related affective self-affinity are socially responsible investing and nationality related ideas. Based on the survey data of 133 active individual investors, we find that the more the investors perceive the company supports/represents a specific group or idea or employ a specific person, with which the investors identify themselves, the higher is the investors' affective self-affinity for the company. This results in higher extra affective motivation to invest in the company's stock over and beyond financial indicators. Thus, investors' identification with groups, people, or ideas such as socially responsible investing and nationality results in higher affect-based investment motivation through affective self-affinity aroused in the investors. Moreover, positive attitude towards the company is another factor that explains the affect-based extra investment motivation.
\end{abstract}

(c) 2017 Elsevier Inc. All rights reserved.

\section{Introduction}

Economic theorists have long held the rationality principle which suggests that the rational agents are simply preference maximizers given all available market constraints and information which is processed under strict Bayesian statistical principles (McFadden et al., 1999). Following this stream, the traditional finance literature assumes that while making investment choices, investors maximize their expected return for a given level of risk given all market information (Clark-Murphy and Soutar, 2004). However, this type of rational-agent model is challenged by the psychological views that individuals' behavior is influenced by the interactions of perceptions, motives, attitudes and affect. Hence their decision may deviate from the optimal decision suggested by the rational-agent model (Kahneman, 2003). As such, the field of behavioral finance has grown to attempt to understand the various influences that affect investor behavior beyond the fundamentals of a pure monetary incentive (Mokhtar, 2014).

\footnotetext{
* Corresponding author.

E-mail addresses: geredeli@bilkent.edu.tr (N. Usul),yozlem@metu.edu.tr

(Ö. Özdemir), kiessling@bilkent.edu.tr (T. Kiessling).
}

Investors do not have all available information and have limited time to process it. So, they develop shortcuts and make their investment decisions based on heuristics and biases (Ackert and Deaves, 2009). The affect heuristic (a mental shortcut that allows people to make decisions and solve problems quickly and efficiently, in which emotions of fear, pleasure, surprise, etc. influences decisions) is one of those shortcuts, studied heavily in the literature. Affective heuristics research has suggested that affective reactions guide information processing and judgment (Zajonc, 1980), especially in uncertain and complex decisions (Loewenstein et al., 2001; Mellers, 2000). Damasio (1994) refers to emotions as "an integral component of the machinery of reason". He indicates that reason and emotions are in such a close interplay that when a potential outcome of an action is associated with positive (negative) feelings then it becomes a beacon of incentive (alarm) (Damasio, 1994). Affective heuristics play a significant role not only in the final decision but also in setting the alternatives to be considered. Among the thousands of stocks, investors often consider purchasing the stocks that were the first to attract their attention (Barber and Odean, 2008). Likewise, research has suggested that affectladen imagery from word associations are predictive of preferences for investing in new companies on the stock market (MacGregor et al., 2000). Even though affect-based decisions are quicker, easier 
and more efficient in complex decisions, they can be faulty as they are subject to manipulation and inherent bias (Slovic et al., 2007).

Behavioral finance research proposes a stochastic discount factor based upon investors' sentiment relative to the fundamental value of the stock as the behavioral portion of the purchase decision is significant (Shefrin, 2008). Several recent studies underline the significance of the psychological affect in people's decision making mechanism (see Slovic et al., 2002, 2007; Finucane et al., 2000; MacGregor et al., 2000) suggesting that an investment is not an isolated mechanism and can also be influenced by factors other than financial returns and risk such as the affective evaluations concerning the company brands and corporate images (Statman et al., 2008; Ang et al., 2010; Freider and Subrahmanyam, 2005; Schoenbachler et al., 2004).

Our cross disciplinary research extends the behavioral finance research by exploring in particular how the affect heuristic may influence investors' decisions with a foundation in marketing, psychology and finance. Our theoretical foundation is social identity theory (SIT) (Tajfel, 1978, 1981; Tajfel and Turner, 1985; Turner, $1975,1982,1984,1985)$ to explain how investors identify themselves with groups, people, and finally ideas/ideals and how these identifications may result in an increase in the affective investment motivation in the company's stock. The marketing research has a long history of customer-corporation identity/brand connection and social identity theory, suggesting that firms attract and retain customers who become loyal and repeat purchasers. When there is a connection between a customer's sense of self and a firm, a deep and mutual relationship develops (Bhattacharya and Sen, 2003) as customers use the symbolic properties of the relationship to communicate their identities (Press and Arnould, 2011). Firms in turn benefit from repeat purchase and price premiums (Lam, 2012). We examine the implications of investor identity to a firm and purchase intention.

The purpose of this study is, hence, to explore the relationship between an investor's affective self-affinity (ASA hereafter) for a company, its antecedents and their purchase intention of a stock. We have found very little research that explored this relationship. ASA is an investor's perception of the congruence between the company and their own personal identity (an identity which may be associated with people, groups of people or ideas and ideals, etc.) (Aspara et al., 2008). Past research has shown that an investor's identification with a company has a positive effect on their determination to invest over similar firms that have relatively similar return (Aspara and Tikkanen, 2011b). Further research by Aspara and Tikkanen (2011a) has indicated ASA and positive attitude may explain the affect-based extra investment motivation. Our research, furthers this stream by suggesting that three dimensions of identification, specifically; group related, company-people related and idea/ideal related, may create extra affective investment motivation by increasing ASA towards a company. Hence, we identify three antecedents which influence ASA aroused in the investor. By treating ASA as a mediator, we study the effects of the antecedents of ASA on the affect-based extra investment motivation. We choose two dimensions, namely socially-responsible investing (SRI hereafter) related ideas and nationality related ideas, as representatives of idea/ideal related ASA since past research shows that they influence individuals' consumption and investment decisions significantly (Statman, 2004; see the extant literature in Section 2.2). Thus, our study contributes to the existing literature by connecting the heavily studied literatures of "Affect", "Social Identity Theory", "Socially Responsible Investing", and "Nationalism and Home Bias".

Our results indicate that as positive attitude towards the investee company increases, the affect-based extra investment motivation increases. Our major contribution that adds to the emerging stream of literature; group-related ASA, company-people related
ASA and idea/ideal related ASA are all significantly and positively mediated by ASA and have significant effects on affect-based extra investment motivation both directly and indirectly. In summary, if firms can develop ASA, then investors will tend to hold their shareholdings and invest more into their firm.

\section{Literature review and hypotheses development}

\subsection{Affective self-affinity $\mathcal{E}$ positive attitude}

Past research has focused on ASA and its influence on decision making (e.g. Slovic et al., 2002, 2007; Finucane et al., 2000). Researchers in the finance field investigated the influence of ASA in the stock investment decision due to the paradoxical return and risk evaluations (high expected return-low risk) of stocks of companies by investors which are associated with strong positive affect (Statman et al., 2008). In a similar manner, a study by Ang et al. (2010) demonstrated how ASA for "class A" shares results in higher valuation by investors compared to "class B" shares of the same companies.

There is a dearth of research that studies the specific relationship between the extra investment motivation to invest in companies and affective/attitudinal evaluations. However recent behavioral finance research focused on the impact of ASA towards companies' brands and corporate images on the willingness to invest in those companies (Aspara and Tikkanen, 2008, 2010a, 2010b; Frieder and Subrahmanyam, 2005; Schoenbachler et al., 2004), and examined the relationship between the affect-based extra investment motivation and two explanatory variables; positive attitude towards the company and ASA (Aspara and Tikkanen, 2011a). The results from this research indicate that a positive attitude towards a company and ASA for a company causes investors to have extra motivation to invest in a company's stock after controlling for several demographic and investor characteristics. As such, we follow the foundation of the literature and first test their hypothesis concerning the attitudinal evaluation and then we further the stream of research and develop hypotheses regarding affective evaluation and the antecedents of ASA.

The first hypothesis concerns the relationship between the positive attitude towards the company and the affect-based extra investment motivation. As suggested by the literature positive attitude always involves affect beside cognitive associations (Eagly et al., 1994; Eagly and Chaiken,1993; Zanna and Rempel, 1998; Breckler and Wiggins,1989a, b). Hence, we assume that an overall affective evaluation towards a company manifests as overall attitude, indicating how much a person likes/dislikes the object (Ajzen and Fishbein, 1980). Individuals may use those overall feelings to guide judgments (Damasio, 1994; Slovic et al., 2002; Zajonc, 1980), particularly in complex decisions where it is difficult to judge pros and cons of various alternatives such as the investment alternatives (Statman et al., 2008). That is why we hypothesize that as positive attitude towards the company increases, the affect-based extra investment motivation gets stronger.

H1: As positive attitude of an individual towards a company increases, his/her affect-based extra investment motivation to invest in the company's stock, over and beyond its expected return and risk, increases.

\subsection{Social identity theory, affective self-affinity and its antecedents}

Affect may also manifest as identification, especially at the higher levels. Our theoretical foundation is social identity theory (SIT) which helps explain the relationship of ASA aroused in people and its antecedents (Tajfel, 1978, 1981; Tajfel and Turner, 1985; Turner, 1975, 1982, 1984, 1985; Aspara et al., 2008). According to 
SIT, people identify themselves with social groups and this makes the social identity of a person which shapes the self-concept of him/her (Tajfel and Turner, 1985; Ashforth and Mael, 1989; Kramer, 1991). This is the categorization of an individual's self with some particular domains whereby the self refers to a social unit instead of a unique person (Brewer, 1991; Turner et al., 1974). Once categorizing self into, or identifying self with a social group, the cognition, perception, and behavior starts to be regulated by the specific group standards; a process called "depersonalization" (e.g. Hogg, 1992, pp. 94; Turner, 1987, pp. 50-51).

In addition to the cognitive side (self-categorization), evaluative (group self-esteem) and emotional (affective) components of the social identity has attracted attention from researchers (Ellemers et al., 1999). The affective component of the identification - which is understudied in the literature but highly suggested to be in the agenda for future research by Brown (2000) - is the main determinant of in-group favoritism (Ellemers et al., 1999). This idea is quite similar to that of Brewer (1979) which puts SIT as "a theory of in-group love rather than out-group hate". Moreover, the prototypical similarity between the group members is the basis for the attraction (liking) among the group members (Hogg et al., 1995). Hence, the affective component of the social identity ties up the discussion to the antecedents of ASA, specifically to group related ASA, implying that individuals may assign affective significance to group identification (Aspara et al., 2008).

Individuals may also identify themselves with abstract ideas/ideals such as nationality/national heritage (Nuttavithisit, 2005), corporate social responsibility (CSR hereafter) (Sen et al., 2006: Bhattacharya et al., 2009; Currás-Pérez et al., 2009) high status (Sirgy, 1982), natural health (Thompson and Troester, 2002), etc. In the same manner, people may identify themselves with people according to the social identity theory (Ashforth and Mael, 1989; Hogg and Voughan, 2002; Tajfel and Turner, 1985; Ahearne et al., 2005) since personnel is perceived as essential to the identity of a company (Balmer, 1995; Harris and De Chernatory,2001; Jo Hatch and Schultz, 1997). Considering the affective component of the social identity theory along with individuals' identification with people and ideas/ideals, individuals may have ASA's for ideas/ideals and for people.

We argue that antecedents of ASA and their effect on investment motivation can be modeled in a path analysis. The antecedents of ASA are proposed by Aspara et al. (2008) in qualitative research, but its relationship with ASA and affect-based extra investment motivation has not been studied empirically. Specifically, we can explore the effect of group related ASA, company-people related ASA and finally idea/ideal related ASA on the ASA for the company aroused in the investor which will, in turn, influence the extra affective motivation to invest in the company's stock. As individuals identify themselves with groups, ideas/ideals, and people, they well may have ASA's for groups, ideas/ideals and people since identification has affective conclusions. Thus, when "a certain group is perceived to be essential for the identity of a company" (Aspara et al., 2008, pp.11), the ASA for the specific group is transferred to the company itself. Likewise, when a person is employed by a company and hence perceived to be "essential for the identity of that company", the ASA for a specific person is transferred to the company (Aspara et al., 2008). The same mechanism is valid for idea/ideal related ASA: If the idea/ideal, with which an individual identify himself/herself, is perceived to be essential for a company, then the ASA for the specific idea/ideal is transferred to the company (Aspara et al., 2008).

Following Statman (2004), we propose two main ideas contributing to idea/ideal related ASA, namely, SRI related ideas and nationality related ideas. As Domini (1992) and Hamilton et al. (1993) refer; SRI is the expression of a desire for an "integration of money into one's self and into the self, one wishes to become."
Investors engaging in socially responsible investment decisions are said to "mix money with morality" in the decision making process (Diltz, 1995). Hence, they filter out the products or stock offerings taking the compatibility of the parent company with their beliefs and values into account (Kelley and Elm, 2003). Thus, companies may use CSR to distinguish themselves, if they are successfully managing CSR related activities (Sen et al., 2006; Drumwright, 1994). With the extant literature on SRI, it can be concluded that "SRI related ideas" is one of the ideas influencing investment decision. Considering the literature on dimensions of corporate social responsibility and socially responsible investing (Carrol, 1979; Martin, 1986; Porter and Kramer, 2002; Saiia, 2002; Hill et al., 2003; Rivoli, 2003; Dillenburg et al., 2003; Guay et al., 2004; Hill et al., 2007; Dahlsrud, 2008; Adams and Hardwick, 1998; Heinkel et al., 2001), and the screens used by the most ethical funds around the world (Spencer, 2001; Belsie, 2001; Hill et al., 2003, 2007; Guay et al., 2004; Renneboog et al., 2008), we hypothesized it to be a formative construct, which is formed by four factors; animal-welfare, environmental responsibility, fair labor practices, and volunteer activities.

The next indicator contributing to idea/ideal related ASA, nationality-related ideas, is among the abstract ideas that individuals identify themselves with (Nuttavuthisit, 2005). Its effect on the consumption decision has been studied as "Consumer nationalism" and "national loyalty" in the marketing literature (see Rawwas et al., 1996; Wang, 2005; Baughn and Yaprak, 1993). Over 60 country-of-origin (CO) research studies have studied the effect of nationalism on the consumption decision, and the effect is evident in the literature (see Samiee (1994) for an overview of the 60 studies; e.g. Han, 1988; Shimp and Sharma, 1987). Since stockholding/ownership can be viewed as experiential consumption which is consistent with the idea that goods that can be consumed are not limited to physical products and services but also include experiences (Solomon et al., 2002) - national loyalty or consumer nationalism can be adapted to stock investment decision as well. A nationalist consumer considers the domestic economy in his/her consumption decision and prefers domestic brands. He/she perceives buying imported products as ruining the economy and as unpatriotic (Rawwas et al., 1996). Accordingly, a nationalist investor is hypothesized to have a tendency to prefer stocks of the companies which are perceived to contribute to national development. This idea of favoring domestic equity investment is presented in detail in the home bias literature as well. The home bias literature discusses the tendency of the investors to invest in the domestic equities heavily despite the international diversification benefits (see Lewis, 1999 for a detailed literature on equity and consumption home biases). Accordingly, the negative effect of patriotism on the investment abroad is demonstrated by Morse and Shive (2011), revealing that patriotism is, indeed, influential on the investment decision.

Following the detailed discussion presented, the hypotheses concerning the antecedents of ASA to be tested in this study are:

H2a: The stronger the ASA an individual has for an idea or ideal, the stronger the ASA he/she has for a company perceived to support or to represent it, which will result in stronger affect-based investment motivation.

$\mathbf{H 2} \mathbf{b}_{\mathbf{b}}$ : The stronger the ASA an individual has for a group of people, the stronger ASA he/she has for a company perceived to support or to represent it, which will result in stronger affect-based investment motivation.

$\mathbf{H 2} \mathbf{c}$ : The stronger the ASA an individual has for a person, the stronger the ASA he/she has for a company perceived to employ that person, which will result in stronger affect-based investment motivation. 


\section{Methodology}

\subsection{Survey design and measurement}

We have formative, reflective, and single item measures as well as single order and higher order latent variables. The dependent latent variable; affect-based extra investment motivation and the independent latent variable positive attitude towards the company and the mediator variable ASA towards the company are based on the research of Aspara and Tikkanen (2011a).

Affect-based extra investment motivation is measured by a reflective two-item scale as:

1. "When you invested in [company X]'s stock, on what basis did you make the investment decision?"

$0=$ "I purchased [company X]'s stock because considering all the investment opportunities I was aware of, I expected to obtain the absolutely best possible financial returns relative to risk from [company X]'s stock."

6= "I purchased [company X]'s stock simply because I liked [company $X]$ as a company."

2. $0=$ "I purchased [company X]'s stock because considering all the investment opportunities I was aware of, I expected to obtain the absolutely best possible financial returns relative to risk from [company X]'s stock."

$6=$ "I purchased [company X]'s stock because I had a positive attitude towards [company X]."

The reason why we chose a Likert scale is because it detects deviation from "pure financial motivation" which corresponds to zero on the scale. This deviation -meaning the extra motivation which is affect-based on top of the financial motivations- is our dependent variable. We are not arguing that financial motivations don't exist in the stock investment decisions. However, what we are arguing is that there could be affect-based motivations over and beyond the financial motivations. So, any deviation from zero on this scale will show different degrees of affect-based motivations revealed in the investment decision.

Positive attitude towards the company is measured by a reflective two-item scale, anchored by:

1. "What kind of attitude did you have towards [company X]?" $-3=$ "very negative", $+3=$ "very positive"

2. "Did you like the products of [company X]?" $-3=$ "didn't like at all", $+3=$ "liked very much"

ASA towards the company is measured by a question adapted from Bergami and Bagozzi (2000), anchored by:

"How well did [company X] reflect the kind of person you are?" $0=$ "not at all", $6=$ "very well".

The following antecedents of ASA measures are created based on research by Aspara et al. (2008). We include three antecedents, namely group-related ASA, company-people related ASA, and idea/ideal related ASA in the model. 1) Group-related ASA and 2) Company-people related ASA are both measured by 5 points Likert scale type questions as follows;

Please identify yourself on the 5 points Likert scale below where: $1=$ "absolutely don't agree", $5=$ "absolutely agree"

1. "I think that [company X] is supportive to and reflects the groups I like and I feel close to."

2. "I think that [company X] employs the people I like and I feel close to."
Idea/Ideal related ASA is hypothesized to be a hierarchical latent variable including two first order factors; namely SRI related ideas and nationality related ideas. It is difficult to develop a latent variable which involves all the ideas/ideals that an investor may value. However, the aforementioned two ideas are greatly discussed in the literature and they are among the most studied ideas reflected in people's investment and consumption decisions.

As it is explained above, SRI related ideas have different dimensions contributing to the formation of the construct; hence, we hypothesized it to be a formative construct. SRI related ideas are measured by a 5 point Likert scale questions as follows:

Please identify yourself on the 5 points Likert scale below where: $1=$ "absolutely don't agree", $5=$ "absolutely agree"

"I think that [company X] meets my below stated non-financial priorities and concerns:

1) Concerned for animal welfare

2) Environmentally- responsible

3) Concerned for fair labor practices

4) Supportive to social responsibility projects"

The next first order construct; nationality related ideas, is measured by a two-item reflective scale which addresses the ideas national brand, national development, domestic production, domestic capital. It is anchored by 5 points Likert scale type questions as follows:

Please identify yourself on the 5 point Likert scale below where: 1 = "absolutely don't agree", 5= "absolutely agree" "I think that [company X] meets my below stated non-financial priorities and concerns:

1) National brand owner and depends on domestic capital

2) Domestic production and contributes to national development

\subsection{Sampling and data}

The questionnaire is a voluntary-based online survey, sent as a link with a cover letter, and participants were not paid for answering the questionnaire. Our sample of interest is composed of non-professional individual stock investors as the past research suggests that these individuals deviate the most from the rationality assumptions of traditional finance (e.g., Grinblatt and Keloharju, 2000, 2001; Lee et al., 1991; Odean, 1998; Poteshman and Serbin, 2003; Warneryd, 2001). Participants were asked to answer questions about the attitudinal and affective evaluations of their investment decisions in certain companies which are publicly traded companies listed in BIST30. More specifically, four companies which have publicly known brands and products are selected in order to have healthy evaluations about the brand and the products of the companies. ${ }^{1}$

In order to eliminate any potential performance and industry related biases we conducted cluster analysis to BIST companies based on the return and standard deviation of returns during the year prior to the survey, and we made sure that the selected companies are from the same cluster but in different industries. Company 1 is a bank, company 2 is a retailer, company 3 is a holding (conglomerate) and company 4 is a manufacturing firm.

\footnotetext{
${ }^{1}$ In order to distribute our survey to their clients, the intermediaries that we have contacted required us not to disclose the names of investee companies that the participants invested in as it is private information of their customers. Hence, we are required not to provide the names of the investee companies; instead we refer to them as company A, B, C, and D in the paper. However, we provide all the necessary information concerning the selected companies such as the risk and return profiles, their industry, and comparative performances with respect to that industry.
} 
Thus, we select companies with similar return- risk profiles in order to eliminate any potential bias due to performance. In addition, each company's return during the year/quarter prior to the survey is compared with the corresponding industry average to check whether there are any possible performance advantages of the selected companies compared to their industry. Results indicate that the average returns of the selected companies during the year/quarter prior to the survey are below their corresponding industry averages. Hence, we are confident that performance related bias is not a serious concern. The cluster information and company-industry comparison are presented in Appendix A.

In the first step of the questionnaire, respondents choose the company of which they currently hold stocks among the 4 companies presented to them and then continue to the second step to answer the questions based on the investment decision they reveal in the first step. ${ }^{2}$ As a population of interest, individual Turkish stock investors in Turkey, especially in the three biggest cities in Turkey; namely Istanbul, Ankara and Izmir, are selected (total population of close to 20 million). The online survey was sent to all intermediary agencies in Turkey via email and the follow up calls are made only to several intermediary bank/agency offices and head offices in the three biggest cities. Note that almost 55\% of the branches and almost $50 \%$ of the head offices of all intermediary agencies are located in these biggest 3 cities. Moreover, the contacted intermediary agencies account for $33 \%$ of the transaction volume in Turkey. ${ }^{3}$ Hence, the sample is potentially an indicator of the Turkish stock investors who are investing in the specific 4 companies.

We sent 363 requests, and received 151 replies in total. Following Aspara and Tikkanen (2011a), we screened away the individuals who reported negative attitudinal evaluation which reflects the overall affective evaluation about the company as our hypotheses are only applicable to individuals who have positive affect (as opposed to negative) towards the company. So, 13 of the replies were screened away due to negative attitude and 5 of them were eliminated because they were incomplete. So, after eliminating unusable and incomplete replies, we end up with 133 usable answers which yield a fairly good response rate of $36.6 \%$ When we compare the answers that arrived early with those that arrived late, we see no significant differences between the two groups, which signal that non-response bias was not a serious concern. The resulting sample of 133 replies is appropriate for the methodology used (see Chin and Newsted, 1999).

When we compare our sample with the Turkish stock investor population, we observe a quite similar profile. Our sample indicates a female-male ratio of $25.6 \%-74.4 \%$ respectively, which is almost the same as that of the population which is $25.2 \%-74.8 \%^{4}$ respectively. When the age distribution is concerned, however, our sample has much higher young investor respondents than the actual data reveals. This is not surprising as the participation rate of younger population to online surveys is higher compared to that of older population (Bech and Kirstensen, 2009; Graefe et al., 2011; Kaplowitz et al., 2005).

The descriptive statistics for the investors participated in the study are demonstrated with respect to the four companies in the Appendix B. The table shows the demographic variables such as gender, age, marital status, education, and income as well as investor characteristics such as tracking activity, risk attitude, investor size, and financial literacy. ${ }^{5}$ The overall characteristics of the

\footnotetext{
2 Each respondent takes the questionnaire only for one company and we did not encounter a case in which the respondent selected more than one company.

3 Source: www.cmb.gov.tr.

4 Source: https://www.mkk.com.tr/en/.

5 The data for the average holding period, which is another indicator of the investor characteristics, was also collected in order to be included as a control
}

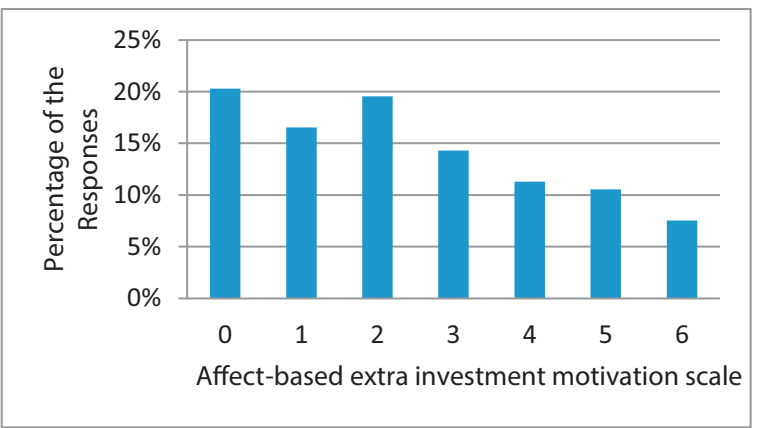

Fig. 1. Frequency distribution of answers to the affect-based extra investment motivation question.

individual investors participated in the study are middle aged, university or higher educated, moderately risk averse and small investors with a fundamental financial literacy. In general, the data does not reveal significant differences between the characteristics of different company investors except for number of stocks owned, investor size, tracking activity, and financial literacy. This confirms our assumption that the investors of the firms in this study are from the same population.

\section{Analyses and results}

Fig. 1 illustrates the responses to the first item of affectbased extra investment motivation question. $80 \%$ of the respondents show affect-based extra investment motivation, either low or high in magnitude, which is averaged to be around 2.5. This supports our presumption that the investors may have extra affectbased motivations in the investment decision. The responses to the main variables in the model are also presented in the Appendix C, to provide a general picture of the tendencies of the answers.

Following Aspara and Tikkanen (2011a) we chose to use Partial Least Squares Structural Path Modeling, PLS-PM. PLS-PM has gained wider usage among empirical researchers due to less restrictive assumptions concerning the data than CBSEM techniques (e.g. sample size, data distribution, independency of observations, indicator type, etc.) as well as its superior convergence, reduced computational demands and exploratory capabilities in the absence of a theoretical foundation (Henseler et al., 2009; Sosik et al., 2009; Chin and Newsted, 1999; Fornell and Cha [1994]). Specifically, we use the software SmartPLS, developed by Ringle et al. (2015). Significance results are based on a bootstrapping procedure with 2000 resamples as suggested by Hair et al. (2011).

As suggested by Chin (1998), we employed a two-step evaluation of the model. At the first step the measurement model is tested for internal consistency and construct validity separately for reflective and formative measures, at the second step structural paths are tested for significance. All reflective constructs exhibit good internal consistency implied by high Cronbach's alphas ${ }^{6}$ and composite reliability scores ${ }^{7}$; exceeding the threshold of 0.70 (Nunnally and Bernstein, 1994). Construct validity is attained by a combination of discriminant validity and convergent validity. Convergent validity is supported by high $\mathrm{AVE}^{8}$; above the threshold

variable in the model. But since it is missing in more than half of the responses, it is excluded from the path model.

6 Reflective constructs; affect, positive attitude, nationality related ideas, reveal Cronbach's alpha scores of $0.908,0.773$, and 0.870 respectively.

7 Reflective constructs; affect, positive attitude, nationality related ideas, reveal composite reliability scores of $0.956,0.898$, and 0.936 respectively.

8 Reflective constructs; affect, positive attitude, nationality related ideas, reveal average variance extracted score of $0.916,0.815$, and 0.880 respectively. 
Table 1

\begin{tabular}{|c|c|c|c|c|c|c|c|c|c|c|c|}
\hline MTMM MATRIX & 1 & 2 & 3 & 4 & 5 & 6 & 7 & 8 & 9 & 10 & 11 \\
\hline 1. Animal welfare & 1 & & & & & & & & & & \\
\hline $\begin{array}{l}\text { 2. Environmental- } \\
\text { responsibility }\end{array}$ & $.779^{* *}$ & 1 & & & & & & & & & \\
\hline 3. Fair labor practices & $.562^{* *}$ & $.553^{* *}$ & 1 & & & & & & & & \\
\hline 4. Volunteer activities & $.606^{* *}$ & $.639^{* *}$ & $.472^{* *}$ & 1 & & & & & & & \\
\hline 5. SRI related ideas & $.906^{* *}$ & $.913^{* *}$ & $.721^{* *}$ & $.795^{* *}$ & 1 & & & & & & \\
\hline $\begin{array}{l}\text { 6. Affect-based } \\
\text { investment } \\
\text { motivation }\end{array}$ & .158 & .022 & .134 & .042 & .101 & 1 & & & & & \\
\hline $\begin{array}{l}\text { 7. Positive attitude } \\
\text { towards the } \\
\text { company }\end{array}$ & $.324^{* *}$ & $.358^{* *}$ & $.302^{* *}$ & $.239^{* *}$ & $.365^{* *}$ & $.345^{* *}$ & 1 & & & & \\
\hline 8. ASA & $.307^{* *}$ & $.310^{* *}$ & $.246^{* *}$ & $.271^{* *}$ & $.339^{* *}$ & $.346^{* *}$ & $.649^{* *}$ & 1 & & & \\
\hline 9. Group related ASA & $.304^{* *}$ & $.299^{* *}$ & $.244^{* *}$ & $.176^{*}$ & $.308^{* *}$ & $.341^{* *}$ & $.476^{* *}$ & $.580^{* *}$ & 1 & & \\
\hline $\begin{array}{l}\text { 10. Company-people } \\
\text { related ASA }\end{array}$ & $.421^{* *}$ & $.467^{* *}$ & $.307^{* *}$ & $.352^{* *}$ & $.469^{* *}$ & $.183^{*}$ & $.405^{* *}$ & $.535^{* *}$ & $.621^{* *}$ & 1 & \\
\hline $\begin{array}{l}\text { 11. Nationality related } \\
\text { ideas }\end{array}$ & $.299^{* *}$ & $.217^{*}$ & $.227^{* *}$ & $.217^{*}$ & $.283^{* *}$ & $.342^{* *}$ & $.402^{* *}$ & $.304^{* *}$ & $.423^{* *}$ & $.212^{*}$ & 1 \\
\hline
\end{tabular}

of 0.50 as suggested by Fornell and Larcker (1981). Concerning discriminant validity, we use HTMT criterion which is shown to have superior performance compared to the classical approaches of Fornell-Larcker criterion and cross loadings (Henseler et al., 2015). All of the HTMT values ${ }^{9}$ are below the conservative threshold of 0.85 , implying good discriminant validity (Kline, 2015). Thus, reflective constructs meet the reliability and validity requirements.

Concerning the formative construct, SRI related ideas, we assess the weights of the indicators and VIF scores for construct reliability and evaluate modified MTMM matrix for discriminant validity as suggested by Andreev et al. (2009). All of the indicator weights in SRI related ideas are above the threshold value of $0.10^{10}$ (Andreev et al., 2009). As Diamantopoulos and Winklhofer (2001) suggest insignificant indicators are preserved since they represent the domain aspect which is theoretically explained above. Multicollinearity seems not to be an issue, as it is addressed by VIF scores lower than $3.3^{11}$ (Diamantopoulos and Siguaw, 2006). Finally, Table 1 presents the modified MTMM matrix which addresses indicator-to-construct, and construct-toconstruct correlations. Correlations between the constructs are all below the threshold value of 0.71 (MacKenzie et al., 2005), indicating good discriminant validity. Moreover, indicator-to-construct correlations reveal that the 4 indicators are more correlated with their corresponding construct than they are with the other constructs. Hence discriminant validity is established.

Fig. 2 demonstrates the last construct; idea/ideal related ASA, which is a second order formative construct, composed of two first order factors; SRI related ideas and nationality related ideas. Following Becker et al. (2012), we employ two-stage approach with mode B for the hierarchical model. At stage one, the outer weights and loadings are calculated for the first order variables; SRI related ideas and nationality related ideas. At the second stage, the latent variable scores for the first order variables are used as indicators

\footnotetext{
${ }^{9}$ HTMT values for affect-positive attitude, affect-nationality related ideas and positive attitude-nationality related ideas are $0.409,0.394$ and 0.477 respectively.

10 Weights of the indicators of the formative construct, SRI related ideas are 0.356 for animal welfare, 0.356 for environmental-responsibility, 0.203 for fair labor practices, and 0.259 for volunteer activities.

11 The VIF scores of the indicators of the formative construct, SRI related ideas, are 2.797 for animal welfare, 2.934 for environmental-responsibility, 1.563 for fair labor practices, and 1.811 for volunteer activities.
}

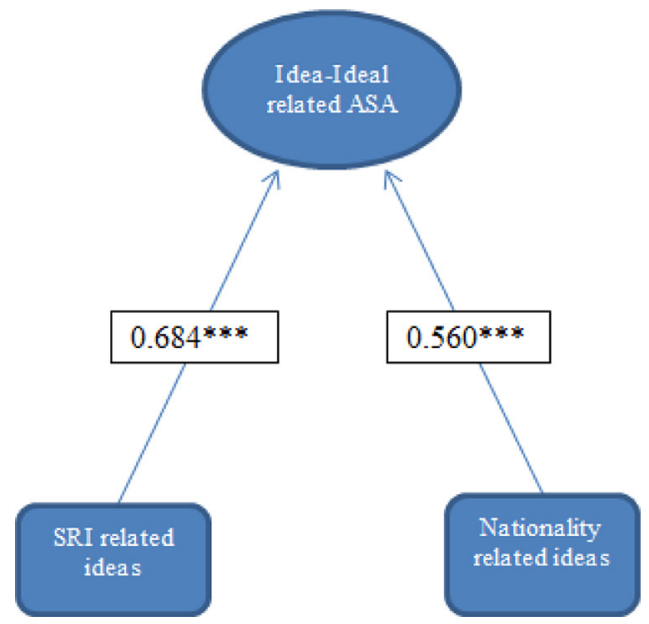

Fig. 2. 2nd order construct idea/ideal related ASA demonstrated with the weights of the 1 st order constructs.

of the second order variable; idea/ideal related ASA. The construct, idea/ideal related ASA exhibit good construct reliability implied by significant indicator weights higher than the threshold of $0.10^{12}$ (Andreev et al., 2009) along with the VIF scores below the threshold value of $3.3^{13}$ (Diamantopoulos and Siguaw, 2006).

Finally, Table 2 presents the modified MTMM matrix for discriminant validity. The discriminant validity of idea/ideal related ASA is supported by low construct-to-construct correlations, which are all below the threshold value of 0.71 (MacKenzie et al., 2005). Moreover, correlations of indicators are higher with their corresponding construct than with others, indicating good discriminant validity. Hence, construct reliability and discriminant validity is established at the second stage as well as at the first stage of the hierarchical latent variable modeling.

\footnotetext{
12 Weights of the indicators of the formative construct; idea/ideal related ASA, are 0.684 for SRI related ideas, and 0.560 for nationality related ideas.

13 The VIF scores of the indicators of the formative construct; idea/ideal related ASA, are 1.088 for both SRI related ideas and nationality related ideas.
} 
Table 2

Multitrait-multimethod matrix (MTMM) analysis for idea/ideal related ASA.

\begin{tabular}{|c|c|c|c|c|c|c|c|c|c|}
\hline \multicolumn{2}{|c|}{ MODIFIED MTMM MATRIX } & 1 & 2 & 3 & 4 & 5 & 6 & 7 & 8 \\
\hline 1. & Nationality related ideas & 1 & & & & & & & \\
\hline 2. & SRI related ideas & $.343^{* *}$ & 1 & & & & & & \\
\hline 3. & Idea/ideal related ASA & $.778^{* *}$ & $.857^{* *}$ & 1 & & & & & \\
\hline 4. & Group related ASA & $.393^{* *}$ & $.308^{* *}$ & $.421^{* *}$ & 1 & & & & \\
\hline 5. & Company-people related ASA & $.292^{* *}$ & $.469^{* *}$ & $.473^{* *}$ & $.621^{* *}$ & 1 & & & \\
\hline 6. & ASA & $.343^{* *}$ & $.339^{* *}$ & $.415^{* *}$ & $.580^{* *}$ & $.535^{* *}$ & 1 & & \\
\hline 7. & $\begin{array}{l}\text { Affect-based extra investment } \\
\text { motivation }\end{array}$ & $.247^{* *}$ & .101 & $.203^{*}$ & $.341^{* *}$ & $.183^{*}$ & $.346^{* *}$ & 1 & \\
\hline 8. & $\begin{array}{l}\text { Positive attitude towards the } \\
\text { company }\end{array}$ & $.413^{* *}$ & $.365^{* *}$ & $.471^{* *}$ & $.476^{* *}$ & $.405^{* *}$ & $.649^{* *}$ & $.344^{* *}$ & 1 \\
\hline & $\begin{array}{l}\text { ct-to-construct correlations are } \mathrm{h} \\
\text { t grey. } \\
\text { orrelation is significant at the } 0 \text {. }\end{array}$ & $\begin{array}{l}\text { hlighted } \\
(0.05) 1\end{array}$ & ith dark & ey. Indi & tor-to-c & struct c & elations & e highli & \\
\hline
\end{tabular}

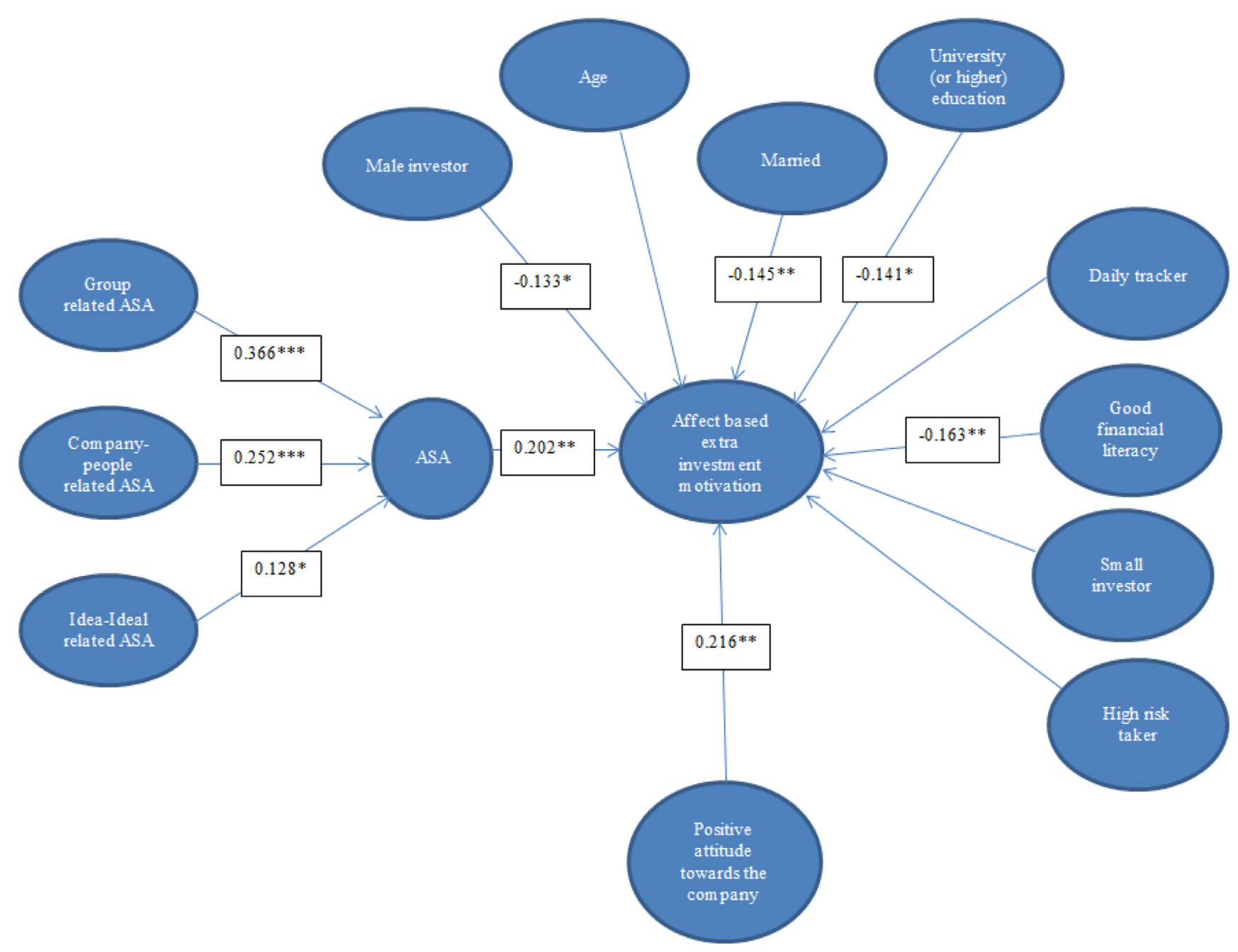

Fig. 3. The structural model with significant paths reported.

Fig. 3 depicts the structural model with significant path coefficients. The model explains $39.8 \%$ of ASA and $38.4 \%$ of Affect-based extra investment motivation.

Table 3 demonstrates the summary of the structural model findings. Positive attitude towards the company has significant direct effect on the dependent variable. As positive attitude towards a company increases affect-based extra investment motivation increases. Likewise, Antecedents of ASA; namely, group related, company-people related, and idea/ideal related ASA's, are significantly mediated by ASA which is significantly correlated with the dependent variable; affect-based extra investment motivation. That is, the antecedents of ASA included in the analysis have significant effects on the ASA aroused in the investor which, in turn, increases the affect-based motivations to invest in the investee company; implying significant indirect effects on the affect based extra investment motivation. Moreover, all of the antecedents of ASA 
Table 3

Summary of the structural model.

\begin{tabular}{|c|c|c|}
\hline Variables & $\begin{array}{l}\text { Path } \\
\text { coeff. }\end{array}$ & $p$-value \\
\hline Positive attitude towards the company -> Affect & 0.216 & $0.034^{* * *}$ \\
\hline Affective self-affinity (ASA) -> Affect & 0.202 & $0.023^{* *}$ \\
\hline Group related ASA $->$ ASA & 0.366 & $0^{* * *}$ \\
\hline Idea/ideal related ASA -> ASA & 0.128 & $0.089^{*}$ \\
\hline Company-people related ASA -> ASA & 0.252 & $0.002^{* * * * *}$ \\
\hline Group related ASA -> Affect & 0.074 & $0.037^{* *}$ \\
\hline Idea/ideal related ASA -> Affect & 0.026 & 0.145 \\
\hline Company-people related ASA -> Affect & 0.051 & $0.053^{*}$ \\
\hline \multicolumn{3}{|l|}{ Controls } \\
\hline Age $->$ Affect & 0.059 & 0.261 \\
\hline Male investor -> Affect & -0.133 & $0.054^{*}$ \\
\hline Married -> Affect & -0.145 & $0.05^{* *}$ \\
\hline University education -> Affect & -0.141 & $0.052^{*}$ \\
\hline Daily tracker -> Affect & -0.011 & 0.447 \\
\hline Good financial literacy -> Affect & -0.163 & $0.011^{* *}$ \\
\hline High risk taker -> Affect & -0.080 & 0.182 \\
\hline Small investor -> Affect & -0.012 & 0.45 \\
\hline \multicolumn{3}{|l|}{ Company dummy controls } \\
\hline Investee company 1 -> Affect & -0.235 & $0.021^{* *}$ \\
\hline Investee company 2 -> Affect & 0.093 & 0.202 \\
\hline Investee company 3 -> Affect & 0.010 & 0.46 \\
\hline \multicolumn{3}{|l|}{ Company dummy moderators } \\
\hline ASA for the company* Investee company $1->$ Affect & -0.149 & 0.143 \\
\hline ASA for the company* Investee company $2->$ Affect & 0.046 & 0.357 \\
\hline ASA for the company*Investee company 3 -> Affect & -0.002 & 0.493 \\
\hline $\begin{array}{l}\text { Attitude towards the company* Investee company } 1-> \\
\text { Affect }\end{array}$ & 0.051 & 0.348 \\
\hline $\begin{array}{l}\text { Attitude towards the company* Investee company } 2-> \\
\text { Affect }\end{array}$ & 0.036 & 0.387 \\
\hline $\begin{array}{l}\text { Attitude towards the company* Investee company } 3 \text {-> } \\
\text { Affect }\end{array}$ & -0.095 & 0.261 \\
\hline
\end{tabular}

except for idea/ideal related ASA, have significant direct effects on the extra affective investment motivation.

Group related and company-people related ASA's have higher significance than the idea/ideal related ASA variable in the indirect paths. As for the idea/ideal related ASA, we included only two dimensions, SRI related ideas and nationality related ideas, which have been studied heavily in the literature. Increasing the dimensions of this variable, hence covering more ideas/ideal, may result in higher significances. Moreover, idea/ideal related ASA does not have significant direct paths to the main dependent variable whereas the other two antecedents have significant direct paths. Hence, the idea/ideal related ASA is fully mediated by the mediator variable, ASA, whereas the other two antecedents are not. Increasing the dimension of the idea/ideal related ASA may also influence the significance of direct path from idea/ideal related ASA to the affect-based extra investment motivation. The signs of the coefficients are all as we expected, confirming our hypotheses. An increase in any of the antecedents increases the affective self- affinity towards the investee company which will further increase the affect-based extra investment motivation.

Most of the company dummy controls and interaction effects are insignificant; except for company 1 dummy. Thus, there seem to be no difference in the findings between different companies. As for the controls, male investors demonstrate less affect-based extra investment motivation compared to female investors (consistent with De Acedo Lizarraga, 2007). The same effect follows for married investors. Likewise, investors with higher education (university or higher) and with higher reported financial literacy, show less affect-based motivations in investment decision (consistent with Forgas, 1995).
Table 4

Summary of the structural model with performance dummy.

\begin{tabular}{lll}
\hline Variables & $\begin{array}{l}\text { Path } \\
\text { coeff. }\end{array}$ & $p$-value \\
\hline Positive attitude towards the company -> Affect & 0.259 & $0.011^{* *}$ \\
Affective self-affinity (ASA) -> Affect & 0.197 & $0.027^{* *}$ \\
Group related ASA -> ASA & 0.366 & $0^{* * *}$ \\
Idea/ideal related ASA -> ASA & 0.128 & $0.084^{*}$ \\
Company-people related ASA -> ASA & 0.252 & $0.001^{* * *}$ \\
Group related ASA -> Affect & 0.072 & $0.046^{* *}$ \\
Idea/ideal related ASA -> Affect & 0.025 & 0.143 \\
Company-people related ASA -> Affect & 0.05 & $0.055^{*}$ \\
Controls & & \\
Age -> Affect & 0.113 & 0.128 \\
Male investor -> Affect & -0.069 & 0.212 \\
Married -> Affect & -0.175 & $0.016^{* *}$ \\
University education -> Affect & -0.13 & $0.051^{*}$ \\
Daily tracker -> Affect & -0.053 & 0.252 \\
Good financial literacy -> Affect & -0.158 & $0.006^{* * *}$ \\
High risk taker -> Affect & -0.129 & $0.063^{*}$ \\
Small investor -> Affect & -0.052 & 0.303 \\
Good performance -> Affect & 0.069 & 0.196 \\
Performance dummy moderators & & \\
Positive attitude towards the company*Good performance & -0.088 & 0.257 \\
- > affect & & \\
ASA * Good performance -> affect & 0.02 & 0.42 \\
\hline
\end{tabular}

*** Significant at the 0.01 level (1-tailed)

** Significant at the 0.05 level (1-tailed).

* Significant at the 0.1 level (1-tailed).

Although the four companies have similar return/risk profiles according to the cluster analysis, and don't have a performance advantage compared to the corresponding industry we further test for good performance by including a good performance dummy in the path model. Table 4 presents the results for the structural model with performance dummy. Results indicate that the good performance dummy fails to be significant along with the dummy moderators. Moreover, significance levels and the coefficients of the main variables are almost the same as the previous results. So, we are confident that the results we present are not subject to performance related bias.

\section{Conclusion}

The current paper has several contributions to the behavioral finance literature. It combines the theoretical background of the marketing, social psychology and finance to explain the affective and attitudinal evaluations of companies influence on the investment decision in the company's stock. More specifically, it examines the antecedents of affective self-affinity (ASA) - namely, group related ASA, company-people related ASA, and idea/ideal related ASA - and how they are related to the ASA for the company and affect-based extra investment motivations empirically.

The results of the study suggest that as the ASA increases for a specific person, for a specific group, and/or a specific idea/ideal increase, the ASA for the company which employs that particular person, supports that particular group, or supports that particular idea/ideal also increases. The ideas discussed in this study are socially responsible investing (SRI) related ideas and nationality related ideas. In other words, as individuals' ASA for SRI related ideas increases, their ASA for a company supporting that idea or engaging in activities which feeds or signals that idea will also increase. In a similar manner, as individuals' ASA for nationality related ideas increases, their ASA for the company supporting that idea or engaging in activities which feeds or signals that idea will also increase. Furthermore, any increase in ASA results in an increase in the affective investment motivation to the particular company's stock. Likewise, positive attitude towards the investee 
company may further explain the extra affective investment motivation. Hence, companies may use people, groups, and/or different ideas/ideals such as SRI related ideas and nationality related ideas to create a bond between the company and the investor. This may, in turn, create extra motivation for investment into those companies' stocks.

Our results have implications for both researchers and practitioners. For researchers in the behavioral finance field, it is necessary to incorporate marketing, sociology, psychology, etc. to understand the dynamics of investors since past research has suggested that investors are influenced by other externalities and do not necessarily always behave rationally in their investing decisions. We have introduced ASA from the marketing field with a foundation of SIT to assist in attempting to further the field in explaining investing decisions. As SIT suggests that individuals identify themselves with groups, people, ideas/ideals and companies, our research suggests that investors do identify themselves with certain aspects of a firm and will invest accordingly. The implications for practitioners suggest that investors are motivated by externalities over and beyond basic numerical data. As such, externalities such as SRI or nationality can influence investors. Top managers can utilize this knowledge to influence current and future investors by strategically focusing on positioning their firm favorably in the eyes of the potential investor to develop ASA. From a marketing point of view, communicating such aspects to the public is beneficial for the company because it attracts the particular investor profile that is sensitive about those aspects. From a finance point of view, however, ASA may work against the fundamentals and hence mitigate the financial efficiency especially when affective and cognitive cues are diverging. The literature suggests that in such instances, the affective side tends to dominate the final decision (Ness and Klaas, 1994; Rolls, 1999). Yet, there is a conflicting experimental study suggesting that as the number of cognitive cues increases it outweighs the affective cues which results in a decision that does not work against the efficiency of the financial markets (Su et al., 2010).

There are certain limitations in this study. Due to the restrictions on the data concerning the contact information of the stock investors in Turkey our sample size is limited, yet we feel we were able to accumulate enough data for the methodology used. As suggested by Falk and Miller (1992) and Shamir et al. (2000); five observations per parameter is the minimum requirement to be able to use PLS modeling. In our model, the largest structural model includes four latent variables which require a minimum of twenty observations. Our dataset meets this requirement, yet, it is important to replicate the study to make more generalizable conclusions. We are aware of more conservative recommendations such as 10 observations per parameter though (Chin and Newsted, 1999; Hair et al., 2011). The size of our sample could be an issue in evaluating the significance of the structural paths. As Chin and Newsted (1999) argue by using Monte Carlo simulations that low structural path coefficients are difficult to detect in studies with small sample sizes (such as 20). So, this works against us in detecting the significant paths, meaning the ones that we detect may probably get higher significance when the sample size gets higher.

In addition, the data concerning the affective evaluations of the companies are self-reported which may create some biases. First of all, we don't have the information regarding the timing of the particular investment decision so we cannot control for it being relatively recent. However, we know that the participants hold the stocks at the time they take the questionnaire. Given that the average holding period for Turkish stock investors in Turkey has averaged to be 79.2 days and has never been greater than 103 days between 2011 and $2015,{ }^{14}$ we may be confident to some extent that the decision was made relatively recent (especially when it is compared to similar studies which refers to 1.5 year time period as recent (Aspara and Tikkanen (2011a)). However, it would be better to control for the timing of the investment to alleviate the possibility of "recalling wrong" as much as possible. Even if we had the timing of the investment and accept the responses with recent investment decisions, individuals may still not correctly recall the motivations underlying the investment decision. This may lead to retrospection related biases in which respondents exaggerate their positive evaluations about the company by committing to the past investment decision (Bem, 1972). However, we may also consider that even if they cannot recall correctly their affective evaluation about the company and motivations in investing the stock of the company, they may engage in self-impression management which could result in over rationalizing accounts of the respondents due to the natural tendency to rationalize the behavior. That is, our findings concerning the affect-based motivations in stock investment may even be more conservative than the actual state.

The measures of antecedents of ASA, although based on past research, are used empirically for the first time in our study. By nature, PLS-PM is successful in exploring the possible relationships which have not been studied before. Although the validity and reliability indicators of the new measures are strong, replicating our study with different measures will be a necessary next step.

In the current study, we collected the responses regarding an investment decision of the investor because we are interested in whether there exists an extra motivation which is affect-based in addition to the financial motivations when an individual makes an investment decision. However, collecting the individuals' evaluations regarding the firms that were considered for investment but were not chosen in the final decision would be beneficial in understanding the relationship between the degree of affect (whether high or low) and the final investment decision (whether to invest or not to invest). This would provide further insights about the affect mechanism and how it manifests itself in the final decision. This is left for further research.

Note also that, in the current study we did not address the effects of negative attitude/negative affective evaluations towards the company on the investment decision (whether to invest or not to invest) and motivation. The resulting effect of negative attitudes/affective evaluations on the investment decision may be simply the negative of that of positive attitudes/affective evaluations. However, it is not necessarily the case. The hypotheses of the current study are based on the literature of positive affective/attitudinal evaluations, identification, affect and emotions (Zajonc, 1980; Damasio, 1994, 2003; Slovic et al., 2002. See Aspara et al. (2008) for a detailed discussion), and consistency between those evaluations and behavior (Abelson et al., 1968; Festinger, 1957; McGuire, 1969). The opposite side of the story, meaning the effect of negative attitude/affective evaluations towards a company on the investment/divestment motivation, requires new hypotheses which are based on the corresponding literature. Hence, this is a topic for a separate study which would be grounded on the related theory and needs to be tested empirically. 


\section{Appendix A. Cluster information and company-industry return comparison}

BIST companies are clustered using two stage clustering method with respect to return and standard deviation of return during the year prior to the survey.

\begin{tabular}{|c|c|c|c|c|}
\hline \multicolumn{5}{|l|}{ Cluster information } \\
\hline & Average return & Average standard deviation & & Number of companies \\
\hline Cluster 1 & 0.0001 & 0.0343 & & 199 \\
\hline Cluster 2 & -0.0008 & 0.0215 & & 211 \\
\hline \multicolumn{5}{|c|}{ Company-industry return comparison } \\
\hline Industry & Banks & Retailers & Holding & Manufacturing \\
\hline \multicolumn{5}{|l|}{1 year return comparison } \\
\hline Number of companies & 16 & 10 & 51 & 24 \\
\hline Average industry return* & $-0.054 \%$ & $0.123 \%$ & $0.009 \%$ & $-0.027 \%$ \\
\hline Selected company return* & $-0.095 \%$ & $0.014 \%$ & $0.002 \%$ & $-0.031 \%$ \\
\hline \multicolumn{5}{|l|}{1 quarter return comparison } \\
\hline Number of companies & 16 & 10 & 51 & 24 \\
\hline Average industry return* & $-0.159 \%$ & $-0.070 \%$ & $0.167 \%$ & $-0.015 \%$ \\
\hline Selected company return* & $-0.192 \%$ & $-0.071 \%$ & $0.094 \%$ & $-0.334 \%$ \\
\hline
\end{tabular}

The selected four companies belong to the second cluster.

* Returns are calculated during the year prior to the survey.

* Returns are calculated during the quarter prior to the survey.

Appendix B. Personal \& investor characteristics of the investors participating in the study

\begin{tabular}{|c|c|c|c|c|c|c|c|c|}
\hline Total responses & & $\begin{array}{l}\text { Company } 1 \\
46\end{array}$ & $\begin{array}{l}\text { Company } 2 \\
32\end{array}$ & $\begin{array}{l}\text { Company } 3 \\
33\end{array}$ & $\begin{array}{l}\text { Company } 4 \\
22\end{array}$ & $\begin{array}{l}\text { Overall sample } \\
133\end{array}$ & Chi square & $p$ value \\
\hline \multicolumn{9}{|l|}{ Gender } \\
\hline 1 & Male & $65.2 \%$ & $78.1 \%$ & $87.9 \%$ & $68.2 \%$ & $74.4 \%$ & & \\
\hline \multirow[t]{2}{*}{2} & Female & $34.8 \%$ & $21.9 \%$ & $12.1 \%$ & $31.8 \%$ & $25.6 \%$ & & \\
\hline & Overall sample & $34.6 \%$ & $24.1 \%$ & $24.8 \%$ & $16.5 \%$ & $100.0 \%$ & 5.869 & 0.118 \\
\hline \multicolumn{9}{|l|}{ Age } \\
\hline 1 & $18-25$ & $6.5 \%$ & $6.3 \%$ & $0.0 \%$ & $9.1 \%$ & $5.3 \%$ & & \\
\hline 2 & $26-40$ & $76.1 \%$ & $50.0 \%$ & $63.6 \%$ & $68.2 \%$ & $65.4 \%$ & & \\
\hline 3 & $41-60$ & $15.2 \%$ & $43.8 \%$ & $36.4 \%$ & $22.7 \%$ & $28.6 \%$ & & \\
\hline \multirow[t]{2}{*}{4} & over 60 & $2.2 \%$ & $0.0 \%$ & $0.0 \%$ & $0.0 \%$ & $0.8 \%$ & & \\
\hline & Overall sample & $34.6 \%$ & $24.1 \%$ & $24.8 \%$ & $16.5 \%$ & $100.0 \%$ & 12.859 & 0.169 \\
\hline \multicolumn{9}{|l|}{ Marital status } \\
\hline 1 & Married & $69.6 \%$ & $53.1 \%$ & $78.8 \%$ & $59.1 \%$ & $66.2 \%$ & & \\
\hline 2 & Single & $28.3 \%$ & $40.6 \%$ & $21.2 \%$ & $36.4 \%$ & $30.8 \%$ & & \\
\hline \multirow[t]{2}{*}{3} & Other & $2.2 \%$ & $6.3 \%$ & $0.0 \%$ & $4.5 \%$ & $3.0 \%$ & & \\
\hline & Overall sample & $34.6 \%$ & $24.1 \%$ & $24.8 \%$ & $16.5 \%$ & $100.0 \%$ & 6.557 & 0.364 \\
\hline \multicolumn{9}{|l|}{ Education } \\
\hline 1 & Primary/secondary school & $0.0 \%$ & $0.0 \%$ & $0.0 \%$ & $0.0 \%$ & $\mathbf{0 . 0} \%$ & & \\
\hline 2 & High school & $2.2 \%$ & $0.0 \%$ & $0.0 \%$ & $4.5 \%$ & $1.5 \%$ & & \\
\hline 3 & Vocational high school & $2.2 \%$ & $0.0 \%$ & $0.0 \%$ & $0.0 \%$ & $0.8 \%$ & & \\
\hline 4 & Associate degree/2years college & $2.2 \%$ & $3.1 \%$ & $9.1 \%$ & $4.5 \%$ & $4.5 \%$ & & \\
\hline 5 & College/bachelor & $56.5 \%$ & $65.6 \%$ & $54.5 \%$ & $72.7 \%$ & $60.9 \%$ & & \\
\hline 6 & Master & $32.6 \%$ & $15.6 \%$ & $27.3 \%$ & $18.2 \%$ & $24.8 \%$ & & \\
\hline \multirow[t]{2}{*}{7} & Doctoral degree & $4.3 \%$ & $15.6 \%$ & $9.1 \%$ & $0.0 \%$ & $7.5 \%$ & & \\
\hline & Overall sample & $34.6 \%$ & $24.1 \%$ & $24.8 \%$ & $16.5 \%$ & $100.0 \%$ & 15.434 & 0.421 \\
\hline \multicolumn{9}{|l|}{ Tracking activity } \\
\hline 1 & Several times a day & $65.2 \%$ & $31.3 \%$ & $45.5 \%$ & $27.3 \%$ & $45.9 \%$ & & \\
\hline 2 & Daily & $26.1 \%$ & $56.3 \%$ & $30.3 \%$ & $40.9 \%$ & $36.8 \%$ & & \\
\hline 3 & Weekly & $2.2 \%$ & $9.4 \%$ & $15.2 \%$ & $27.3 \%$ & $11.3 \%$ & & \\
\hline 4 & Monthly & $4.3 \%$ & $3.1 \%$ & $6.1 \%$ & $4.5 \%$ & $4.5 \%$ & & \\
\hline \multirow[t]{2}{*}{5} & Yearly or less than seldom & $2.2 \%$ & $0.0 \%$ & $3.0 \%$ & $0.0 \%$ & $1.5 \%$ & & \\
\hline & Overall sample & $34.6 \%$ & $24.1 \%$ & $24.8 \%$ & $16.5 \%$ & $100.0 \%$ & 22.792 & .030 \\
\hline
\end{tabular}




\begin{tabular}{|c|c|c|c|c|c|c|c|c|}
\hline Total responses & & $\begin{array}{l}\text { Company } 1 \\
46\end{array}$ & $\begin{array}{l}\text { Company } 2 \\
32\end{array}$ & $\begin{array}{l}\text { Company } 3 \\
33\end{array}$ & $\begin{array}{l}\text { Company } 4 \\
22\end{array}$ & $\begin{array}{l}\text { Overall sample } \\
133\end{array}$ & Chi square & $p$ value \\
\hline \multicolumn{9}{|l|}{ Risk attitude } \\
\hline 1 & No risk taker & $0.0 \%$ & $0.0 \%$ & $3.0 \%$ & $0.0 \%$ & $0.8 \%$ & & \\
\hline 2 & Highly risk averse & $6.5 \%$ & $0.0 \%$ & $0.0 \%$ & $9.1 \%$ & $3.8 \%$ & & \\
\hline 3 & Risk averse & $10.9 \%$ & $6.3 \%$ & $9.1 \%$ & $13.6 \%$ & $9.8 \%$ & & \\
\hline 4 & Moderate risk averse & $39.1 \%$ & $56.3 \%$ & $54.5 \%$ & $40.9 \%$ & $47.4 \%$ & & \\
\hline 5 & Risk seeker & $32.6 \%$ & $28.1 \%$ & $21.2 \%$ & $31.8 \%$ & $28.6 \%$ & & \\
\hline 6 & Highly risk seeker & $2.2 \%$ & $6.3 \%$ & $6.1 \%$ & $4.5 \%$ & $4.5 \%$ & & \\
\hline \multirow[t]{2}{*}{7} & Very highly risk seeker & $8.7 \%$ & $3.1 \%$ & $6.1 \%$ & $0.0 \%$ & $5.3 \%$ & & \\
\hline & Overall sample & $34.6 \%$ & $24.1 \%$ & $24.8 \%$ & $16.5 \%$ & $100.0 \%$ & 15.054 & 0.658 \\
\hline \multicolumn{9}{|l|}{ Investor size } \\
\hline 1 & Small investor & $87.0 \%$ & $62.5 \%$ & $66.7 \%$ & $81.8 \%$ & $75.2 \%$ & & \\
\hline 2 & Medium-sized investor & $13.0 \%$ & $37.5 \%$ & $27.3 \%$ & $18.2 \%$ & $23.3 \%$ & & \\
\hline \multirow[t]{2}{*}{3} & Large investor & $0.0 \%$ & $0.0 \%$ & $6.1 \%$ & $0.0 \%$ & $1.5 \%$ & & \\
\hline & Overall sample & $34.6 \%$ & $24.1 \%$ & $24.8 \%$ & $16.5 \%$ & $100.0 \%$ & 13.356 & 0.038 \\
\hline \multicolumn{9}{|l|}{ Financial literacy } \\
\hline 1 & Can do technical analysis & $52.2 \%$ & $28.1 \%$ & $33.3 \%$ & $22.7 \%$ & $36.8 \%$ & & \\
\hline 2 & Have a fundamental knowledge & $39.1 \%$ & $71.9 \%$ & $45.5 \%$ & $54.5 \%$ & $51.1 \%$ & & \\
\hline 3 & Have a little knowledge & $6.5 \%$ & $0.0 \%$ & $15.2 \%$ & $22.7 \%$ & $9.8 \%$ & & \\
\hline 4 & Don't have a clear idea & $2.2 \%$ & $0.0 \%$ & $6.1 \%$ & $0.0 \%$ & $2.3 \%$ & & \\
\hline \multirow[t]{2}{*}{5} & Don't have an idea & $0.0 \%$ & $0.0 \%$ & $0.0 \%$ & $0.0 \%$ & $0.0 \%$ & & \\
\hline & Overall sample & $34.6 \%$ & $24.1 \%$ & $24.8 \%$ & $16.5 \%$ & $100.0 \%$ & 20.858 & 0.013 \\
\hline
\end{tabular}

Appendix $C$. The breakdown of the responses to the main variables in the model

\begin{tabular}{|c|c|c|c|c|c|c|}
\hline \multirow[t]{3}{*}{ Scale } & \multicolumn{6}{|l|}{ The variables } \\
\hline & \multicolumn{2}{|c|}{ Affect-based extra investment motivation } & \multirow[t]{2}{*}{ Affective self-affinity (ASA) } & & & \\
\hline & Item 1 & Item 2 & & & & \\
\hline 0 & $20 \%$ & $21 \%$ & $3 \%$ & & & \\
\hline 1 & $17 \%$ & $19 \%$ & $4 \%$ & & & \\
\hline 2 & $20 \%$ & $15 \%$ & $11 \%$ & & & \\
\hline 3 & $14 \%$ & $17 \%$ & $9 \%$ & & & \\
\hline 4 & $11 \%$ & $9 \%$ & $23 \%$ & & & \\
\hline 5 & $11 \%$ & $12 \%$ & $43 \%$ & & & \\
\hline 6 & $8 \%$ & $8 \%$ & $7 \%$ & & & \\
\hline \multirow[t]{3}{*}{ Mean } & 2.4 & 2.4 & 4.0 & & & \\
\hline & \multicolumn{6}{|c|}{ Positive attitude toward the company* } \\
\hline & Item 1 & Item 2 & & & & \\
\hline 0 & $11 \%$ & $10 \%$ & & & & \\
\hline 1 & $34 \%$ & $20 \%$ & & & & \\
\hline 2 & $37 \%$ & $51 \%$ & & & & \\
\hline 3 & $18 \%$ & $19 \%$ & & & & \\
\hline \multirow[t]{3}{*}{ Mean } & 1.6 & 1.8 & & & & \\
\hline & \multicolumn{6}{|c|}{ Antecedents of affective self-affinity (ASA) } \\
\hline & Group related ASA & Company-people related ASA & & & & \\
\hline 1 & $10 \%$ & $13 \%$ & & & & \\
\hline 2 & $17 \%$ & $17 \%$ & & & & \\
\hline 3 & $18 \%$ & $22 \%$ & & & & \\
\hline 4 & $28 \%$ & $31 \%$ & & & & \\
\hline 5 & $27 \%$ & $17 \%$ & & & & \\
\hline \multirow[t]{4}{*}{ Mean } & 3.5 & 3.2 & & & & \\
\hline & \multicolumn{6}{|c|}{ Idea-ideal related ASA } \\
\hline & \multicolumn{4}{|c|}{ Socially-responsible investing related ideas } & \multicolumn{2}{|c|}{ Nationality-related ideas } \\
\hline & Item 1 & Item2 & Item3 & Item4 & Item 1 & Item 2 \\
\hline 1 & $2 \%$ & $3 \%$ & $0 \%$ & $2 \%$ & $4 \%$ & $5 \%$ \\
\hline 2 & $7 \%$ & $5 \%$ & $9 \%$ & $4 \%$ & $8 \%$ & $14 \%$ \\
\hline 3 & $59 \%$ & $42 \%$ & $42 \%$ & $36 \%$ & $16 \%$ & $13 \%$ \\
\hline 4 & $19 \%$ & $38 \%$ & $34 \%$ & $42 \%$ & $37 \%$ & $29 \%$ \\
\hline 5 & $14 \%$ & $12 \%$ & $15 \%$ & $17 \%$ & $35 \%$ & $39 \%$ \\
\hline Mean & 3.3 & 3.5 & 3.5 & 3.7 & 3.9 & 3.8 \\
\hline
\end{tabular}

* Note: The responses with negative scores on this variable are eliminated from the sample as we are interested in the positive attitude rather than negative attitude towards the company. 


\section{References}

Abelson, R.P., Aronson, E., McGuire, W.J., Newcomb, T.M., Rosenberg, M.J., Tannenbaum, P.H. (Eds.), 1968, Theories of Cognitive Consistency: A Sourcebook. Rand McNally, Chicago.

Ackert, L., Deaves, R., 2009. Behavioral Finance: Psychology, Decision-making, and Markets. Cengage Learning.

Adams, M., Hardwick, P., 1998. An analysis of corporate donations: United Kingdom evidence. J. Manag. Stud. 35, 641-654.

Ahearne, M., Bhattacharya, C.B., Gruen, T., 2005. Antecedents and consequences of customer-company identification: expanding the role of relationship marketing. J. Appl. Psychol. 90 (3), 574-585.

Ajzen, I., Fishbein, M., 1980. Understanding and Predicting Social Behavior. Prentice Hall, Englewood Cliffs, NJ.

Andreev, P., Heart, T., Maoz, H., Pliskin, N., 2009. Validating formative partial least squares (PLS) models: methodological review and empirical illustration. In: Proceedings of the Thirtieth International Conference on Information Systems. Phoenix, Arizona.

Ang, J.S., Chua, A., Jiang, D., 2010. Is A better than B? How affect influences the marketing and pricing of financial securities. Financ. Analysts J. 66, 40-54.

Ashforth, B.E., Mael, F., 1989. Social identity theory and the organization. Acad. Manage. Rev. 14 (1), 20-39.

Aspara, J., Olkkonen, R., Tikkanen, H., Moisander, J., Parvinen, P., 2008. A theory of affective self-affinity: definitions and application to a company and its business. Acad. Market. Sci. Rev. 12 (3), 1.

Aspara, J., Tikkanen, H., 2008. Interactions of individuals' company-related attitudes and their buying of the companies' stocks and products. J. Behav. Finance 9, 85-94.

Aspara, J., Tikkanen, H., 2010a. Consumers' stock preferences beyond expected financial returns: the influence of product and brand evaluations. Int. J. Bank Market. 28, 193-221.

Aspara, J., Tikkanen, H., 2010b. The role of company affect in stock investments: towards blind, undemanding, non-comparative, and committed love. J. Behav. Finance 11, 103-113.

Aspara, J., Tikkanen, H., 2011a. Individuals' affect-based motivations to invest in stocks: beyond expected financial returns and risks. J. Behav. Finance 12 (2), 78-89.

Aspara, J., Tikkanen, H., 2011b. Corporate marketing in the stock market: the impact of company identification on individuals' investment behavior. Eur. J. Market. 45 (9/10), 1446-1469.

Balmer, J.M.T., 1995. Corporate identity: the power and the paradox. Des. Manage. J. 6 (1), 39-44 (Former Series)

Barber, B.M., Odean, T., 2008. All that glitters: The effect of attention and news on the buying behavior of individual and institutional investors. Rev. Financ. Stud. 21 (2), 785-818

Baughn, C.C., Yaprak, A., 1993. Mapping country-of-origin research: recent developments and emerging avenues. In: Papadopoulos, N., Heslop, L. (Eds.), Product Country Images: Impact and Role in International Marketing. Haworth Press, New York, pp. 89-115.

Bech, M., Kristensen, M.B., 2009. Differential response rates in postal and web-based surveys among older respondents. Surv. Res. Methods 3, 1-6.

Becker, J.-M., Klein, K., Wetzels, M., 2012. Hierarchical latent variable models in PLS-SEM: guidelines for using reflective-formative type models. Long Range Plann. 45 (5), 359-394.

Belsie, L., 2001. Rise of the name-brand fund: a few aurity groups help investors put their money where their hearts are. Christian Sci. Monit. 13 (August), 16.

Bem, D.J., 1972. Self-perception theory. Adv. Exp. Soc. Psychol. 6, 1-62.

Bergami, M., Bagozzi, R.P., 2000. Self-categorization and commitment as distinct aspects of social identity in the organization: conceptualization, measurement, and relation to antecedents and consequences. Br. J. Soc. Psychol. 39, 555-577.

Bhattacharya, C.B., Sen, S., 2003. Consumer-company identification: a framework for understanding consumers' relationships with companies. J. Market. 67 (2) $76-88$.

Bhattacharya, C.B., Korschun, D., Sen, S., 2009. Strengthening stakeholder-company relationships through mutually beneficial corporate social responsibility initiatives. J. Bus. Ethics 85 (2), 257-272.

Breckler, S.J., Wiggins, E.C., 1989a. Affect versus evaluation in the structure of attitudes. J. Exp. Soc. Psychol. 25 (3), 253-271.

Breckler, S.J., Wiggins, E.C., 1989b. Scales for the measurement of attitudes toward blood donation. Transfusion 29, 401-404.

Brewer, M.B., 1979. In-Group Bias in the Minimal intergroup situation: a cognitivemotivational analysis. Psychol. Bull. 86 (2), 307-324.

Brewer, M.B., 1991. The social self: on being the same and different at the same time. Pers. Soc. Psychol. Bull. 17 (5), 475-482.

Brown, R., 2000. Social identity theory: past achievements, current problems and future challenges. Eur. J. Soc. Psychol. 30 (6), 745-778.

Carroll, A.B., 1979. A three-dimensional conceptual model of corporate social performance. Acad. Manage. Rev. 4, 497-505.

Chin, W.W., 1998. The partial least squares approach to structural equation modeling. In: Marcoulides, G.A. (Ed.), Modern Methods for Business Research. Lawrence Erlbaum Associates, New Jersey, pp. 295-336.

Chin, W.W., Newsted, P.R., 1999. Structural equation modeling analysis with small samples using partial least squares. In: Hoyle, R.H. (Ed.), Statistical Strategies for Small Sample Research. Sage, Thousand Oaks, CA, pp. 307-342.

Clark-Murphy, M., Soutar, G.N., 2004. What individual investors value: some Australian evidence. J. Econ. Psychol. 25 (4), 539-555.
Currás-Pérez, R., Bigné-Alcañiz, E., Alvarado-Herrera, A., 2009. The role of self-defnitional principles in consumer identification with a socially responsible company. J. Bus. Ethics 89 (4), 547-564.

Dahlsrud, A., 2008. How corporate social responsibility is defined: an analysis of 37 definitions. Corporate Soc. Responsibility Env. Manage. 15, 1-13.

Damasio, A.R., 1994. Descartes' Error: Emotion, Rationality and the Human Brain. Putnam, New York.

Damasio, A.R., 2003. Looking for Spinoza: Joy, Sorrow, and the Feeling Brain. Houghton Mifflin Harcourt.

de Acedo, L., Sanz, M.L., 2007. Factors that Affect decision making: gender and age differences. Int. J. Psychol. Psychol. Ther. 7 (3), 381-391.

Diamantopoulos, A., Winklhofer, H.M., 2001. Index construction with formative indicators: an alternative to scale development. J. Market. Res. 38 (2), 269-277.

Diamantopoulos, A., Siguaw, J.A., 2006. Formative versus reflective indicators in organizational measure development: a comparison and empirical illustration. $\mathrm{Br}$. J. Manage. 17 (4), 263-282.

Dillenburg, S., Greene, T., Erekson, O.H., 2003. Approaching socially responsible investment with a comprehensive rating scale: total social impact. J. Bus. Ethics 43, 167-177.

Diltz, J.D., 1995. Does social screening affect portfolio performance? J. Investing 4, 64-69.

Domini, A., 1992. What is social investing? Who are social investors?. In: Kinder, P.D., Lydenberg, S.D., Domini, A.L. (Eds.) The Social Investment Almanac. Henry Holt and Company, New York, pp. 5-7.

Drumwright, M.E., 1994. Socially responsible organizational buying: environmental concern as a noneconomic guying criterion. J. Market. 58 (3), 1-19.

Eagly, A.H., Mladinic, A., Otto, S., 1994. Cognitive and affective bases of attitudes toward social groups and social policies. J. Exp. Soc. Psychol. 30 (2), 113-137.

Eagly, A.H., Chaiken, S., 1993. The Psychology of Attitudes. Harcourt Brace Jovanovich College Publishers.

Ellemers, N., Kortekaas, P., Ouwerkerk, J.W., 1999. Self-categorization, commitment to the group and group self-esteem as related but distinct aspects of social identity. Eur. J. Soc. Psychol. 29 (23), 371-389.

Falk, R.F., Miller, N.B., 1992. A Primer for Soft Modeling. University of Akron Press, Akron, $\mathrm{OH}$.

Festinger, L., 1957. A Theory of Cognitive Dissonance. Stanford University Press, Stanford, CA.

Forgas, J.P., 1995. Mood and judgment: the affect infusion model (AIM). Psychol. Bull. 117 (1), 39-66.

Fornell, C., Cha, J., 1994. Partial least squares. In: Bagozzi, R.P. (Ed.), Advanced Methods of Marketing Research. Blackwell Publishers, Cambridge, USA, pp. 52-78.

Fornell, C., Larcker, D.F., 1981. Structural equation models with unobservable variables and measurement error: algebra and statistics. J. Market. Res. 18, 382-388.

Finucane, M.L., Alhakami, A., Slovic, P., Johnson, S.M., 2000. The affect heuristic in judgments of risks and benefits. J. Behav. Decis. Making 13, 1-17.

Frieder, L., Subrahmanyam, A., 2005. Brand perceptions and the market for common stock. J. Financ. Quant. Anal. 40, 57-85.

Graefe, A., Mowen, A., Covelli, E., Trauntvein, N., 2011. Recreation participation an conservation attitudes: differences between mail and online respondents in a mixed-mode survey. Hum. Dimensions Wildlife 16, 183-199.

Grinblatt, M., Keloharju, M., 2000. The investment behavior and performance of various investor types: a study of Finland's unique data set. J. Financ. Econ. 55 (1) $43-67$.

Grinblatt, M., Keloharju, M., 2001. How distance, language, and culture influence stockholdings and trades. J. Finance 56 (3), 1053-1073.

Guay, T., Doh, J.P., Sinclair, G., 2004. Non-governmental organizations, shareholder activism, and socially responsible investments: ethical, strategic, and governance implications. J. Bus. Ethics 52 (1), 125-139.

Hair, J.F., Ringle, C.M., Sarstedt, M., 2011. PLS-SEM: indeed, a silver bullet. J. Market. Theory Pract. 19, 139-151.

Hamilton, S., Jo, H., Statman, M., 1993. Doing well while doing good? The investment performance of socially responsible mutual funds. Financ. Anal. J. 49, 62-66.

Han, C.M., 1988. The effects of cue familiarity on cue utilization: the case of country of origin. Conference of the Academy of International Business.

Harris, F., de Chernatony, L., 2001. Corporate branding and corporate brand performance. Eur. J. Market. 35 (3/4), 441-456.

Heinkel, R., Kraus, A., Zechner, J., 2001. The effect of green investment on corporate behavior. J. Financ. Quant. Anal. 36, 431-449.

Henseler, J., Ringle, C.M., Sarstedt, M., 2015. A new criterion for assessing discriminant validity in variance-based structural equation modeling. J. Acad. Market. Sci. 43 (1), 115-135.

Henseler, J., Ringle, C.M., Sinkovics, R. R, 2009. The use of partial least squares path modeling in international marketing. Adv. Int. Market. 20, 277-320.

Hill, R.P., Ainscough, T., Shank, T., Manullang, D., 2007. Corporate social responsibility and socially responsible investing: a global perspective. J. Bus. Ethics 70, 165-174.

Hill, R.P., Stephens, D., Smith, I., 2003. Corporate social responsibility: an examination of individual firm behavior. Bus. Soc. Rev. 108, 339-362.

Hogg, M.A., 1992. The Social Psychology of Group Cohesiveness: From Attraction to Social Identity. Harvester Wheatsheaf.

Hogg, M.A., Hardie, E.A., Reynolds, K.J., 1995. Prototypical similarity, self-categorization, and depersonalized attraction: a perspective on group cohesiveness. Eur. J. Soc. Psychol. 25 (2), 159-177. 
Hogg, M.A., Vaughan, G., 2002. Social Psychology: An Introduction. Pearson Education.

Jo Hatch, M., Schultz, M., 1997. Relations between organizational culture, identity and image. Eur. J. Market. 31 (5/6), 356-365.

Kahneman, D., 2003. Maps of bounded rationality: psychology for behavioral economics. Am. Econ. Rev. 93 (5), 1449-1475.

Kaplowitz, M.D., Hadlock, T.D., Levine, R., 2005. A comparison of web and mail survey response rates. Public Opin. Q. 68, 94-101.

Kelley, P.C., Elm, D.R., 2003. The effect of context on moral intensity of ethical issues: revising Jones's issue-contingent model. J. Bus. Ethics 48, 139-154.

Kline, R.B., 2015. Principles and Practice of Structural Equation Modeling, fourth ed. Guilford Publications.

Kramer, R.M., 1991. Intergroup relations and organizational dilemmas: the role of categorization processes. Res. Org. Behav. 13, 191-228.

Lam, S.K., 2012. Identity-motivated marketing relationships: research synthesis, controversies, and research agenda. AMS Rev. 2, 72-87.

Lee, C., Shleifer, A., Thaler, R.H., 1991. Investor sentiment and the closed-end fund puzzle. J. Finance 46 (1), 75-109.

Lewis, K.K., 1999. Trying to explain home bias in equities and consumption. J. Econ. Lit. 37 (2), 571-608.

Loewenstein, G.F., Weber, E.U., Hsee, C.K., Ned, W., 2001. Risk as feelings. Psychol. Bull. 127 (2), 267-286.

MacGregor, Gld., Slovic, P., Dreman, D., Berry, M., 2000. Imagery, affect, and financial judgment. J. Psychol. Financ. Markets 1 (2), 104-110.

MacKenzie, S.B., Podsakoff, P.M., Jarvis, C.B., 2005. The problem of measurement model misspecification in behavioral and organizational research and some recommended solutions. J. Appl. Psychol. 90 (4), 710-730.

Martin, J., 1986. Happy returns for do-gooders. Financ. World 18, 32-33.

McFadden, D., Machina, M.J., Baron, J., 1999. Rationality for economists? In: Elicitation of Preferences. Springer, Netherlands, pp. 73-110.

McGuire, W.J., 1969. The nature of attitudes and attitude change. Handbook Soc. Psychol. 3 (2), 136-314.

Mellers, B.A., 2000. Choice and the relative pleasure of consequences. Psychol. Bull. 126 (6), 910-924.

Mokhtar, A.I., 2014. Behavioral finance: investor psychology perspective. J. Finance Investment Anal. 3 (2), 41-60.

Morse, A., Shive, S., 2011. Patriotism in your portfolio. J. Financ. Markets 14 (2), 411-440.

Nesse, R.M., Klaas, R., 1994. Risk perception by patients with anxiety disorders. J. Nerv. Ment. Dis. 182 (8), 466-470.

Nunally, J.C., Bernstein, I.H., 1994. Psychometric Theory, third ed. McGraw-Hill, New York, NY.

Nuttavuthisit, K., 2005. Consumption of national identity and consumers' self identity. Adv. Consum. Res. 32, 243.

Odean, T., 1998. Are investors reluctant to realize their losses? J. Finance 53 (5), $1775-1798$.

Porter, M.E., Kramer, M.R., 2002. The competitive advantage of corporate philanthropy. Harv. Bus. Rev. 80 (12), 56-68.

Poteshman, A.M., Serbin, V., 2003. Clearly irrational financial market behavior: evidence from the early exercise of exchange traded stock options. J. Finance 58 (1), 37-70.

Press, M., Arnould, E.J., 2011. How does organizational identification form? A consumer behavior perspective. J. Consum. Res. 38 (4), 650-666.

Rawwas, M.Y.A., Rajendran, K.N., Wuehrer, G.A., 1996. The influence of world mindedness and nationalism on consumer evaluation of domestic and foreign products. Int. Market. Rev. 13 (2), 20-38.

Renneboog, L., Horst, J.T., Zhang, C., 2008. Socially responsible investments: institutional aspects, performance, and investor behavior. J. Bank. Finance 32 $1723-1742$

Ringle, C.M., Wende, S., and Becker, J.-M., 2015. "SmartPLS 3." Boenningstedt: SmartPLS GmbH, http://www.smartpls.com.

Rivoli, P., 2003. Labor standards in the global economy: issues for investors. J. Bus. Ethics 43, 223-232.

Rolls, E.T., 1999. The Brain and Emotion. Oxford University Press, New York.

Saiia, D.H., 2002. Philanthropy and corporate citizenship: strategic philanthropy is good corporate citizenship. J. Corporate Citizenship 1 (2), 57-74.
Samiee, S., 1994. Customer evaluation of products in a global market. J. Int. Bus. Stud. 25, 579-604.

Schoenbachler, D.D., Gordon, G.L., Aurand, T.W., 2004. Building brand loyalty through individual stock ownership. J. Prod. Brand Manage. 13 (7), 488-497.

Sen, S., Bhattacharya, C.B., Korschun, D., 2006. The role of corporate social responsibility in strengthening multiple stakeholder relationships: a field experiment. J. Acad. Market. Sci. 34, 158-166.

Shamir, B., Zakay, E., Brainin, E., Popper, M., 2000. Leadership and social identification in military units: direct and indirect relationships. J. Appl. Soc. Psychol. 30, 612-640.

Shefrin, H., 2008. A Behavioral Approach to Asset Pricing. Academic Press.

Shimp, T.A., Sharma, S., 1987. Consumer ethnocentrism: construction and validation of the CETSCALE. J. Market. Res. 24 (3), 280-289.

Sirgy, M.J., 1982. Self-concept in consumer behavior: a critical review. J. Consum. Res. 9 (3), 287-300.

Slovic, P., Finucane, M.L., Peters, E., MacGregor, D.G., 2002. Rational actors or rational fools: implications of the affect heuristic for behavioral economics. J. Socio-Econ. 31, 329-342.

Slovic, P., Finucane, M.L., Peters, E., MacGregor, D.G., 2007. The affect heuristic. Eur. J. Oper. Res. 177, 1333-1352.

Solomon, M., Bamossy, G., Askegaard, S., 2002. Consumer Behaviour - A European Perspective, third ed. Pearson Education, Harlow, UK.

Sosik, J.J., Kahai, S.S., Piovoso, M.J., 2009. Silver bullet or voodoo statistics? A primer for using the partial least squares data analytic technique in group and organization research. Group Org. Manage. 34, 5-36.

Spencer, R.D., 2001. Assets in socially screened investments grew by $183 \%$. Employee Benefit Plan Rev. 56, 30-32.

Statman, M., 2004. What do investors want? J. Portfolio Manage. 30, 153-161.

Statman, M., Fisher, K.L., Anginer, D., 2008. Affect in a behavioral asset pricing model. Financ. Anal. J. 64, 20-29.

Su, H.-J., Chang, C.-J., Chuang, S.-C., 2010. The Effect of corporate image as an affect heuristic on investors' decision making. Asia Pac. Manage. Rev. 15 (3), 453-476.

Tajfel, H. (Ed.), 1978, Differentiation Between Social Groups: Studies in the Social Psychology of Intergroup Relations. Academic Press.

Tajfel, H., 1981. Human Groups and Social Categories: Studies in Social Psychology. CUP Archive.

Tajfel, H., Turner, J.C., 1985. The social identity theory of intergroup behavior. In: Worchel, S., Austin, W.G. (Eds.), Psychology of Intergroup Relations. Nelson-Hall, Chicago, pp. 6-24.

Thompson, C.J., Troester, M., 2002. Consumer value systems in the age of postmodern fragmentation: the case of the natural health micro culture. J. Consum. Res. 28 (4), 550-571.

Turner, J.C., 1975. Social comparison and social identity: some prospects for intergroup behaviour. Eur. J. Soc. Psychol. 5 (1), 1-34

Turner, J.C., 1982. Towards a cognitive redefinition of the social group. In: Tajfel, $\mathrm{H}$ (Ed.), Social Identity and Inter Group Relations. Cambridge University Press, Cambridge, England, pp. 15-40.

Turner, J.C., 1984. Social identification and psychological group formation. In: Tajfel, H. (Ed.). In: The Social Dimension: European Development of Social Psychology, 2. Cambridge University Press, Cambridge, UK, pp. 518-538.

Turner, J.C., 1985. Social categorization and the self-concept: a social cognitive theory of group behavior. In: Lawler, E.J. (Ed.). In: Advances in Group Processes: Theory and Research, 2. JAI Press, Greenwich, CT, pp. 77-122.

Turner, J.C., 1987. A self-categorization theory. In: Turner, J.C., Hogg, M.A., Oakes, P.J., Reicher, S.D., Wetherell, M.S. (Eds.), Rediscovering the Social Group: A Self-Categorization Theory. Oxford, New York, Blackwell, pp. 42-67.

Turner, J.C., Hogg, M.A., Oakes, P.J., Reicher, S.D., Wetherell, M.S., 1974. Rediscovering the Social Group: A Self-Categorization Theory. Oxford, New York, Blackwell.

Wang, J., 2005. Consumer nationalism and corporate reputation management in the global era. Corporate Commun. 10 (3), 223-239.

Warneryd, K.-E., 2001. Stock-Market Psychology: How People Value and Trade Stocks. Edward Elgar, Cheltenham, UK.

Zajonc, R.B., 1980. Feeling and thinking: Preferences need no inferences. Am. Psychol. 35 (2), 151-175.

Zanna, M.P., Rempel, J.K., 1998. Attitudes: A New Look at an Old Concept. Cambridge University Press, New York, NY, US 